\title{
INFLUENCE OF ESTROGEN AND PROGESTERONE ON ULTRASTRUCTURAL INDICES OF OVIDUCTAL EPITHELIUM IN SEXUALLY IMMATURE MICE
}

\author{
I. LAUSCHOVÁ \\ Department of Histology and Embryology, Medicine Faculty, Masaryk University, Brno, Czech Republic \\ Received November 11, 1998 \\ Accepted January 14, 1999 \\ Abstract \\ Lau schová I.: Influence of Estrogen and Progesterone on Ultrastructural Indices of Oviductal \\ Epithelium in Sexually Immature Mice. Acta Vet. Brno 1999, 68: 13-21. \\ The influence of estrogen and progesterone on the oviductal epithelium of sexually immature \\ mice aged 14, 21, and 28 days was studied using electron microscopy. These ages were used \\ because the postnatal differentiation of the oviductal epithelium is completed in all substantial \\ features. Each group was divided into three subgroups of 8-10 mice: controls, mice treated with \\ estradiol, and mice treated with estradiol and progesterone. \\ The administration of steroid ovarian hormones generally induced acceleration of the \\ development of oviductal epithelial cells. The ultrastructure of these cells was similar to that of \\ adult mice with normal estrous cycle. While estradiol influenced both ciliated and secretory cells \\ and stimulated their proliferation and differentiation, the ultrastructural marks of increased \\ secretory activity and degeneration of ciliated cells were observed after the progesterone \\ administration. Ultrastructural changes of the oviductal epithelium exposed to exogenous estrogen \\ and progesterone showed distinct regional differences. \\ The height of the epithelium was evaluated as well. The measurement was made, both in controls \\ and animals treated with hormones (mean values of differences of the epithelium height between \\ estrogenized and progesteronized animals were $3.23 \mu \mathrm{m}$ in the preampulla, $4.16 \mu \mathrm{m}$ in the ampulla, \\ and $2.02 \mu \mathrm{m}$ in the isthmus), and also in the all segments of the oviduct: the epithelium is the lowest \\ in the ampulla $(14.25-18.34 \mu \mathrm{m})$, while, conspicuously, the higher epithelium lined the \\ preampullary and isthmic segment (18.04-19.17 $\mu \mathrm{m}$ and 19.97-20.13 $\mu \mathrm{m})$. \\ The results of present study serve to verify the sensitivity of the tubal epithelium of sexually \\ immature mice to exogenous steroid hormones of the ovary and to give preliminary morphological \\ concept for immunohistochemical study of respective hormone receptors.
}

Postnatal development, oviduct, ciliation, secretion, ovarian hormones, mouse

The oviduct serves as an optimal environment for the transport of gametes, fertilization and early development of embryo (Roblero and Garavagno 1979; Fisher et al. 1982; Forceledo et al. 1982; Fuentealba et al. 1988; Nieder and Macon 1987; Abe et al. 1995; Boatman and Magnoni 1995; Lapointe et al. 1995; Kim et al. 1996a). Moreover, papers concerned with cultivation of zygots together with the oviductal epithelial cells, refer to the importance of the oviducts, too (Sathananthan et al. 1990; Takeuchi et al. 1992). Mutual interactions between gametes and oviductal epithelium were studied during their co-cultivation in the medium saturated with steroid hormones (Reuter et al. 1994). An increased secretion of the oviductal epithelium was observed after the administration of both estrogen and progesterone (Erickson-Lawrence et al. 1989; Buhi et al. 1991; B uhi et al. 1992). Sensitivity of the structural components of the oviduct to ovarian steroid hormones was confirmed by several authors, such as Nozaki and Ito (1987), Elsimar and Coutinho (1988), Faussone-Pelegrini and Bani (1990), Hoshino and Kumasaka (1991). Differences in number of hormonal receptors in the 
epithelial cells, fibroblasts of mucosal connective tissue and smooth muscle cells of the external muscle coat of the oviduct during estrous cycle were studied by Puri and Roy (1981), Batra and Iosif (1989), Yamashita et al. (1989). According to Ogunrati (1992) steroidogenic cells producing steroid hormones of tubal fluid were found in the oviductal epithelium

The aim of present paper was to verify the response of the oviductal epithelium of the immature mice after the administration of exogenous estrogen and progesterone on the ultrastructural level.

Animals

Materials and Methods

The oviducts of sexually immature mice $(\mathrm{C} 57 \mathrm{BL} / 10 \times \mathrm{CBA}(\mathrm{F} 1))$ aged 14, 21, and 28 days were used in the present study. The animals of the same age were divided into three groups of $8-10$ animals. Mice of the $1^{\text {st }}$ group were treated with estradiol, those of the $2^{\text {nd }}$ group with estradiol and progesterone. The $3^{\text {rd }}$ group of the examined animals served as intact controls.

Hormones

Microcrystallic water suspensions of steroid hormones were used for stimulation: Agofollin-Depot /Biotika/ (estradioli benzoas $10 \mathrm{mg} / 2 \mathrm{ml}$ ) and Agolutin-Depot /Biotika/ (progesteronum $50 \mathrm{mg} / 2 \mathrm{ml}$ ). Aqua pro injectione /Biotika/ served as a vehiculum for the dilution of both hormones. $1 \mathrm{ml}$ of vehiculum contained the total dose of hormones per day. Hormones as well as vehiculum were administered subcutaneously in the suprascapular region of the experimental animals.

Protocol of hormone administration (see Table 1)

Table 1

\begin{tabular}{|c|c|c|c|c|}
\hline Group & 1st day & 2nd day & 3rd day & 4th day \\
\hline I. & $50 \mu \mathrm{g} / \mathrm{kg} . \mathrm{d} \mathbf{E}_{\mathbf{2}}$ & $50 \mu \mathrm{g} / \mathrm{kg} . \mathrm{d} \mathbf{E}_{\mathbf{2}}$ & $50 \mu \mathrm{g} / \mathrm{kg} \cdot \mathrm{d} \mathbf{E}_{\mathbf{2}}$ & $50 \mu \mathrm{g} / \mathrm{kg} \cdot \mathrm{d} \mathbf{E}_{\mathbf{2}}$ \\
\hline II. & $50 \mu \mathrm{g} / \mathrm{kg} . \mathrm{d} \mathbf{E}_{\mathbf{2}}$ & $50 \mu \mathrm{g} / \mathrm{kg} . \mathrm{d} \mathbf{E}_{\mathbf{2}}$ & $\begin{array}{l}25 \mu \mathrm{g} / \mathrm{kg} . \mathrm{d} \mathbf{E}_{2} \\
50 \mathrm{mg} / \mathrm{kg} . \mathrm{d} \mathbf{P}\end{array}$ & $\begin{array}{l}25 \mu \mathrm{g} / \mathrm{kg} . \mathrm{d} \mathbf{E}_{2} \\
25 \mathrm{mg} / \mathrm{kg} . \mathrm{d} \mathbf{P}\end{array}$ \\
\hline III. (control) & $\begin{array}{l}\text { Aqua pro inj. } \\
(1 \mathrm{ml})\end{array}$ & $\begin{array}{l}\text { Aqua pro inj. } \\
(1 \mathrm{ml})\end{array}$ & $\begin{array}{l}\text { Aqua pro inj. } \\
(1 \mathrm{ml})\end{array}$ & $\begin{array}{l}\text { Aqua pro inj. } \\
(1 \mathrm{ml})\end{array}$ \\
\hline
\end{tabular}

Explanation: $\mathbf{E}_{\mathbf{2}}$ - estradiol, $\mathbf{P}$ - progesterone

Electron microscopy

The animals were killed by decapitation, and oviducts were fixed in toto in $300 \mathrm{mmol} / \mathrm{l}$ glutaraldehyde and 80 $\mathrm{mmol} / \mathrm{l} \mathrm{OsO}_{4}$ in $100 \mathrm{mmol} / \mathrm{l}$ cacodylate buffer, after dehydration, the samples were embedded into Durcupan ACM (Fluka), cut on Ultratome III ultramicrotome and stained with uranyl acetate and lead citrate according to Reynolds (1963). The ultrathin sections were viewed and photographed by transmission electron microscope Tesla BS $500(90 \mathrm{~kW})$.

Height of the epithelium

The height of the epithelium was measured in electron micrographs at magnification $6000 \times$. In each electron micrograph 6-12 measurements of height were made. The obtained data were used for statistical evaluation of significance of differences by means of simple variance analysis (Student's $t$ test).

\section{Results}

Control animals

Day 14

Four types of ciliated cells were identified in the epithelium of the preampulla and ampulla. Type I cells with short microvilli on the luminal surface contained generative complexes in the supranuclear region of the cytoplasm. The generative complex was made up of 2 or more procentrioles arranged radially around deuterosome (Plate VI, Fig.1). Besides generative complexes, microtubules and solitary centrioles were found in some of these cells. Type II cells with microvilli contained numerous centrioles corresponding to 
basal bodies with regard to localization and orientation (Plate VI, Fig. 2). Type III cells were characterized by luminal surface covered partly with cilia, partly with short microvilli. Below the microvillous region of plasmalemma, solitary centrioles were usually present. Type IV cells showed the signs of well differentiated ciliated cells with abundant cilia, covering the whole cell apices. They were classified into two subtypes: the cells with numerous organelles (elongated mitochondria, long tubules of rough endoplasmic reticulum (RER) and 2-3 well developed Golgi apparatuses), and the cells with poor organelle equipment (containing a small amount of spherical mitochondria, a small amount of short tubules of RER and 1 small Golgi apparatus beneath the nucleus).

Secretory cells with secretory granules of different size and maturity level (homogenous and heterogenous immature and homogenous mature granules) were observed in the ampulla and isthmus. The granules were mostly dispersed among cisternae of the RER and Golgi apparatus within the cytoplasm. Tubules and cisternae of both organelles were dilated regularly.

Uniform indifferent cells with microvilli were found in the epithelium of all the segments of the oviduct. These cells occurred in a lesser amount than ciliated and secretory ones. Their cytoplasm contained the abundance of polysomes and elongated mitochondria, while the RER and Golgi apparatus were poorly developed.

The concentric bodies, composed of densely and spirally arranged narrow tubules with glycogen granules among them were observed in secretory and indifferent cells (Plate VII, Fig. 3). The bodies were often localized in the subnuclear zone of the cytoplasm.

Mitoses were sporadically found in the epithelium of all oviductal segments.

\section{Day 21}

Type IV ciliated cells were predominant in the preampullary and ampullary epithelium. The remaining types seen in the oviductal epithelium of the 14-day animals occurred sporadically.

The secretory cells with apically localized mature secretory granules were found among predominated ciliated cells in the preampulla and indifferent cells in the isthmus. The apices of these cells were flat or dome-shaped and protruded into the oviductal lumen. Except well matured cells with secretory granules in their apical protrusions, the secretory cells with dilated profiles of the RER and Golgi apparatus, and scattered immature and mature secretory granules were present in the ampulla. Regardless of localization and level of secretory granules maturation, the concentric bodies were found in many secretory cells.

The density of indifferent cells was higher in the isthmus; in the ampulla and preampulla these cells were observed sporadically. Solitary mitotic figures were also found in the preampulla and ampulla.

Day 28

Ciliated cells were always well differentiated in all the segments of the oviduct. Secretory cells with mature secretory granules in protruding apices and with the concentric bodies were identified in the whole oviduct epithelium. The number of mitotic figures was the same as that in the oviductal epithelium of the 21-day-old animals.

\section{Estrogen}

The occurrence of well differentiated ciliated cells and tall secretory epithelial cells (Plate VII and VIII, Figs. 4, 5-day 28) protruding into the lumen of the oviduct was recorded after the administration of estrogen.

\section{Day 14}

Scattered cells with ciliogenic activity (type II and III cells) were found among type IV cells abundant in the preampulla and ampulla. Well differentiated secretory cells containing 
mature secretory granules lined both the ampullary and isthmic tubal segments. The granules were accumulated in apical regions of the cytoplasm, which constantly protruded into the lumen. The concentric bodies located subnuclearly were typical of secretory cells (Fig. 4).

Days 21 and 28

An ultrastructural appearance of the epithelium corresponded well with the pictures of the oviductal epithelium seen in adults during proestrus and early estrus (Figs. 4, 5). Ciliated cells with marks of ciliogenic activity (type I-III cells) were not observed in any oviductal segment.

Mitotic figures occurred sporadically in the epithelium of the ampullary segment in animals of all age groups. However, the number of such cells was lower than that in controls.

\section{Progesterone}

Day 14, 21 and 28

The progesterone administration after pretreatment of the animals with estradiol caused a reduction in the number of ciliated cells. The height of the epithelium was always decreased and the apices of most secretory cells were flat and only with a few secretory granules (Plate VIII, Fig. 6). Cytoplasmic processes containing secretory granules or smooth electronlucent vesicles were pinched and protruded from the apices of many secretory cells (Plate IX and X, Figs.7, 8, 9); narrow and long stalks connecting the cell apices and cytoplasmic processes were often observed (Plate X, Fig. 10). Cytoplasmic fragments of secretory cells were seen within oviductal lumina (Plate XI, Fig. 11). Moreover, the degenerating ciliated cells, characterized by condensation of nuclear chromatin, mitochondrial defects and vacuolization of the cytoplasm, were found in the epithelium of the preampulla and ampulla (Plate XI, Fig. 12). Mitotic figures were never observed in any oviductal segment.

Height of the epithelium

The results of measurement of the epithelial height are given in Table 2.

Table 2

\begin{tabular}{|c|c|c|c|c|c|c|c|c|c|}
\hline & \multicolumn{3}{|c|}{14} & \multicolumn{3}{|c|}{21} & \multicolumn{3}{|c|}{28} \\
\hline & $\mathrm{P}$ & A & I & $\mathrm{P}$ & A & I & $\mathrm{P}$ & A & I \\
\hline $\mathrm{C}$ & $\begin{array}{l}19.17 \\
\pm 1.74\end{array}$ & $\begin{array}{l}18.34 \\
\pm 1.28\end{array}$ & $\begin{array}{l}20.13 \\
\pm 2.40\end{array}$ & $\begin{array}{l}18.04 \\
\pm 2.07\end{array}$ & $\begin{array}{l}15.75 \\
\pm 0.77\end{array}$ & $\begin{array}{l}20.05 \\
\pm 2.62\end{array}$ & $\begin{array}{l}18.47 \\
\pm 2.37\end{array}$ & $\begin{array}{l}14.25 \\
\pm 3.24\end{array}$ & $\begin{array}{l}19.97 \\
\pm 1.60\end{array}$ \\
\hline $\mathrm{E}$ & $\begin{array}{l}20.89 \\
\pm 1.87\end{array}$ & $\begin{array}{l}19.69 \\
\pm 1.60 *\end{array}$ & $\begin{array}{l}22.20 \\
\pm 4.72\end{array}$ & $\begin{array}{l}20.11 \\
\pm 0.82\end{array}$ & $\begin{array}{l}19.82 \\
\pm 3.15\end{array}$ & $\begin{array}{l}22.37 \\
\pm 1.35\end{array}$ & $\begin{array}{l}19.25 \\
\pm 3.06\end{array}$ & $\begin{array}{l}15.15 \\
\pm 1.44\end{array}$ & $\begin{array}{l}17.47 \\
\pm 2.16\end{array}$ \\
\hline $\mathrm{P}$ & $\begin{array}{l}18.37 \\
\pm 5.36\end{array}$ & $\begin{array}{l}15.23 \\
\pm 1.83\end{array}$ & $\begin{array}{l}21.17 \\
\pm 2.22\end{array}$ & $\begin{array}{l}16.36 \\
\pm 2.16\end{array}$ & $\begin{array}{l}13.75 \\
\pm 1.95 * *\end{array}$ & $\begin{array}{l}19.44 \\
\pm 2.72\end{array}$ & 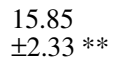 & $\begin{array}{l}13.19 \\
\pm 0.81\end{array}$ & $\begin{array}{l}15.38 \\
\pm 2.08 *\end{array}$ \\
\hline
\end{tabular}

Explanation to the table: $\mathrm{P}$ - preampulla, A - ampulla, I - isthmus, 14,21,28 - age of animals in days, $\mathrm{C}$ - control, $\mathrm{E}$ - estradiol, $\mathrm{P}$ - progesterone, $\mathrm{n}=8$, statistical significance: $\mathrm{p}<0.05(*)$ and $\mathrm{p}<0.01(* *)$, mean value $\pm \mathrm{SEM}$

The oviductal epithelium of control animals aged 14 and 21 days was higher (15.75$20.13 \mu \mathrm{m})$ than that of control animals aged 28 days $(14.25-19.97 \mu \mathrm{m})$. In view of topography of the oviduct, the epithelium is the lowest in the ampulla $(14.25-18.34 \mu \mathrm{m})$, while, conspicuously, the higher epithelium lined the preampullary and isthmic segment (18.04-19.17 $\mu \mathrm{m}$ and 19.97-20.13 $\mu \mathrm{m})$. Statistically significant differences of epithelial height in the animals treated with estradiol or estradiol + progesterone were observed: mean values of differences of the epithelium height between estrogenized and 
progesteronized animals are $3.23 \mu \mathrm{m}$ in the preampulla, $4.16 \mu \mathrm{m}$ in the ampulla, and $2.02 \mu \mathrm{m}$ in the isthmus (see graph).

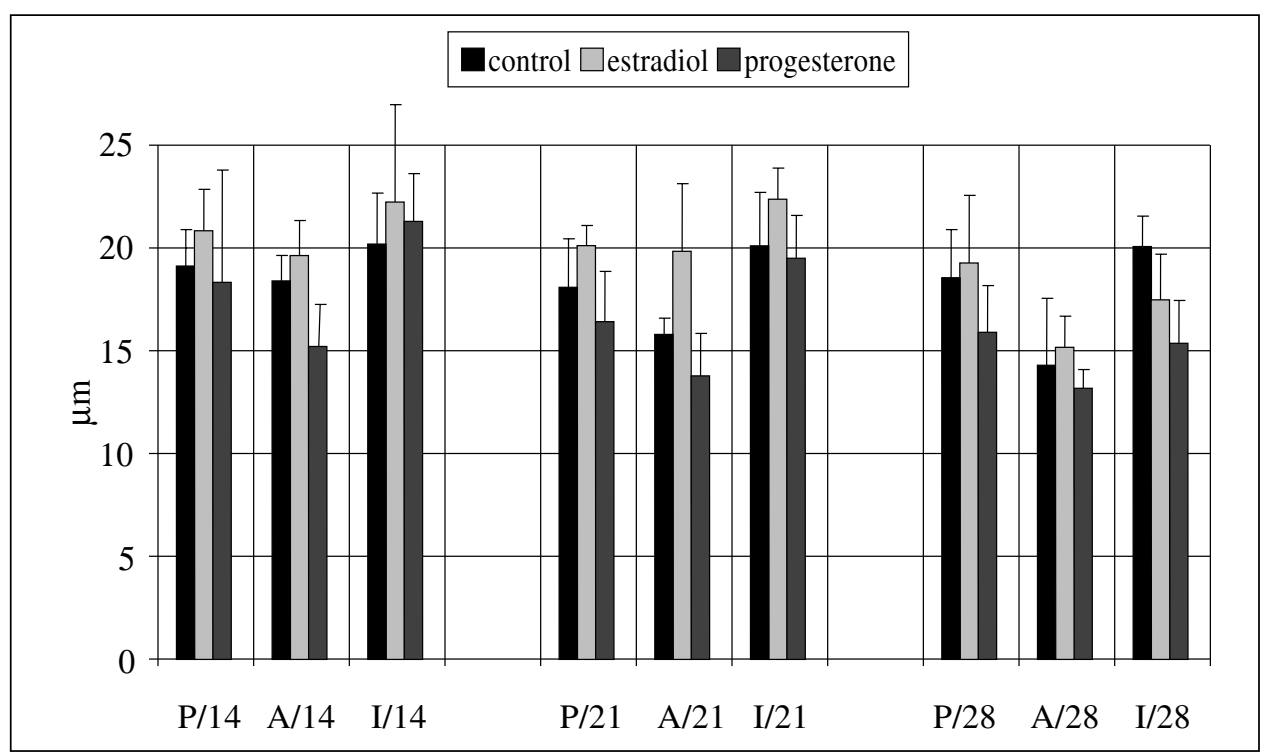

Fig. 13. Influence of estrogen and progesterone on ultrastructural parameters of oviductal epithelium in sexually immature mice

\section{Discussion}

The oviducts of newborn mice are lined with simple columnar epithelium, in which uniform indifferent cells with microvilli and isolated cells showing ciliogenic activity occur. Postnatal changes of the mouse oviductal epithelium from birth to day 14 are characterized by proliferation manifested by the presence of mitotic figures, and by differentiation of ciliated cells (Lauschová 1996). The occurrence of generative complexes with procentrioles and microtubules is one of typical ultrastructural marks of ciliated cells differentiation. The first secretory cells containing immature and mature secretory granules, dispersed in the infra- and perinuclear cytoplasm, were observed in animals aged 14 days. The well-developed rough endoplasmic reticulum and the Golgi apparatus were typical of most developing secretory cells. The concentric bodies located subnuclearly were described in secretory and indifferent cells by Lauschová (1996) and Čech and Lauschová (1996). We first observed them in the oviductal epithelium on day 14. Their number increased to day 28 and decreased from days 28 to 35 after birth. After day 35 and in adult mice the concentric bodies persisted only in the cells lining the isthmus.

The occurrence of the ultrastructural signs of ciliated and secretory cells was lower after hormonal treatment. The number of mitotic figures decreased in the epithelium of estrogenized animals. Mitoses were not observed in the oviducts of progesteronized animals.

After the estrogen administration we observed well differentiated ciliated and secretory cells. These findings agree to the results of other authors (Brenner et al. 1974; Verhage and Brenner 1975; Pathak et al. 1979; Eroschenko 1982; Odor et al. 1980 and 1983; Brenner and Slayden 1994). Malette et al. (1995) have demonstrated the synthesis of specific glycoproteins in secretory cells. 
The influence of progesterone on the oviductal epithelium was manifested by a decrease of the total number of ciliated cells, the epithelium height decrease (Brener and Slay den 1994) and by ultrastructural signs of increased secretory activity (Uhrín 1992). The decrease of ciliated cells number is usually explained as a result of deciliation. GaddumRose et al. (1975) described tufts of cilia in oviducts of postmenopausal women as a clear and doubtless sign of deciliation. B renner (1969) has described a process of separating the apical part of cilium and presented it as "pinching off". This term was used later by Abe and Oikaw a (1990) in the description of the formation of apical cytoplasmic processes in secretory cells. Hollis et al. (1984) have observed ciliated cells showing an apocrine release of apical vesicles on the surface of isthmic ciliated cells, and they claimed that this process was probably not connected with deciliation. We have not observed any ultrastructural evidences, which could be referred to as deciliation marks. On the other hand, some ciliated cells in the degenerative process were seen. By that time, there has not been answered the question, if the decrease of ciliated cells number results only from the deciliation or only degeneration or from both processes. An antiproliferative effect of progesterone was mentioned by Kim et al. (1996b). Saw yer et al. (1984) described the transformation of the columnar ciliated and secretory cells into the cuboidal cells with wrinkled nuclei without nucleoli, and with split apical ends of the cells in the oviductal epithelium. They have found cell fragments and macrophages in the lumen of the oviduct, too.

We have observed the pinched apical parts of the cytoplasm, containing secretory granules, electronlucent vesicles, tubules of the rough endoplasmic reticulum, ribosomes and isolated mitochondria in the epithelium. Some cytoplasmic segregations, usually without any organelles, were connected with the secretory cell apices by long and narrow stalks. The similar structures on the apical surfaces of secretory cells in the oviducts of adult mice during later estrus and metestrus were described by Čech and Lauschová (1990). Abe and Oikawa (1990) found them in the oviducts of a pig during the luteal phase, and used the term "pinching off” for this process. Recently No votný et al. (1998a, b) described protrusions of the apices of the epithelial cells of the endometrium in women during luteal phase and after hormonal treatment. They have referred them, according to the size, as pinopodia and micropinopodia.

Some authors, simultaneously with morphological studies of the oviductal lining in the adults during the estrous cycle, evaluated the height of the epithelial cells. In bovine oviducts Uhrín (1992) found the highest values of the epithelium height during proestrus and estrus $(37.3 \mu \mathrm{m})$; in metestrus and diestrus the height was decreased $(35.8$ and $29.9 \mu \mathrm{m})$. Verhage et al. (1990) have recorded cells between 31-39 $\mu \mathrm{m}$ in the follicular phase and $19-32 \mu \mathrm{m}$ in the luteal phase in a baboon. The differences in height of hormonally treated and non-treated oviductal epithelium exhibited the same trends in our experiments. In addition, we have observed some regional differences in sensitivity of the oviductal epithelium to the ovarian steroid hormones. The differences in the epithelium height after estrogen or progesterone treatment were the highest in the ampulla and the smallest in the isthmus. Similar findings were published by Gupta et al. (1969) and Fredricsson and Holm (1974).

\section{Vliv estrogenu a progesteronu na ultrastrukturní ukazatele tubárního epitelu pohlavně nezralých myší}

Autorka studovala vliv exogenního estrogenu a progesteronu na utrastrukturní znaky tubárního epitelu pohlavně nezralých myší o stáří 14, 21 a 28 dní. Zviŕata uvedených věkových skupin byla vybrána proto, že postnatální diferenciace tubárního epitelu je $\mathrm{v}$ podstatných rysech dokončena. Každá věková skupina byla rozdělena do tří podskupin 
o 8-10 jedincích: kontrolní, ovlivněné estradiolem a ovlivněné estradiolem a progesteronem.

Aplikace steroidních hormonů ovaria urychlila vývoj buněk tubární výstelky, jejíž ultrastrukturní obraz připomíná poměry u dospělých myší s normálním estrálním cyklem. Zatímco estrogeny proliferaci a diferenciaci buněk, a to jak řasinkových, tak sekrečních stimulovaly, progesteron působil zejména na sekreční buňky a indukoval degenerativní změny $\mathrm{v}$ řasinkových buňkách. Ultrastrukturní obraz tubárního epitelu po aplikaci exogenního estrogenu a progesteronu vykazoval zřetelné regionální rozdíly.

Současně se studiem ultrastrukturních charakteristik autorka vyhodnotila výšku epitelu ve všech segmentech vejcovodu u kontrolních zvířat i u zvírat, kterým byly aplikovány steroidní hormony. V ampulle byl epitel nejnižší $(14,25-18,34 \mu \mathrm{m})$, v preampulle a isthmu výška epitelu kolísala v rozmezí 18,04-19,17 $\mu \mathrm{m}$ a 19,97-20,13 $\mu \mathrm{m}$. Stř̌ední hodnoty rozdílů výšky epitelu zvířat „estrogenizovaných“ a ,progesteronizovaných“ činily 3,23 $\mu \mathrm{m}$ v preampulle, $4,16 \mu \mathrm{m}$ v ampulle a $2,02 \mu \mathrm{m}$ v isthmu.

Výsledky studie potvrdily, že tubární epitel pohlavně nezralých myší je senzitivní vůči exogenním steroidním hormonům ovaria a poskytly předběžný morfologický korelát pro cílené imunohistochemické studium př́islušných receptorů.

\section{References}

ABE, H., OIKAWA, T. 1990: Examination by electron microscopy of oviductal epithelium of the prolific chinese Meishan pig at follicular and luteal phases. Anat. Rec. 233: 399-408

ABE, H., SENDAI, Y., SATOH, T., HOSHI, H. 1995: Secretory products of bovine oviductal epithelial cells support viability and motility of bovine spermatozoa in culture in vitro. J. Exp. Zool. 272/1: 54-61

BATRA, S., IOSIF, C. S.1989: Tissue specific effects of progesterone on progesterone and estrogen receptors in the female urogenital tract. J. Steroid. Biochem. 1A: 35-39

BOATMAN, D. E., MAGNONI, G. E. 1995: Identification of a sperm penetration factor in the oviduct of the golden hamster. Biol. Reprod. 52: 199-207

BRENNER, R. M. 1969: Renewal of oviduct cilia during the menstrual cycle of the rhesus monkey. Fertil. Steril. 20: $599-611$

BRENNER, R. M., RESKO, J. A., WEST, N. B.1974: Cyclic changes in oviductal morphology and residual cytoplasmic estradiol binding capacity induce by sequential estradiol-progesterone treatment of spayed rhesus monkeys. Endocrinology 95: 1094-1104

BRENNER, R. M., SLAYDEN, O. D. 1994: Oestrogen action in the endometrium and oviduct of rhesus monkey during RU486 treatment. Human Reprod. 1: 82-97

BUHI, W. C., BAZER, F.W., ALVAREZ, I. M., MIRANDO, M.. 1991: In vitro synthesis of oviductal protein associated with estrus and 17-beta estradiol - treated ovariectomized ewes. Endocrinology 128: 3086-3095

BUHI, W. C., ASHWORTH, C. J., BAZER, F. W., ALVAREZ, I. M. 1992: In vitro synthesis of oviductal secretory proteins by estrogen-treated ovariectomized gilts. J. Exp. Zool. 262: 426-435

ČECH, S., LAUSCHOVÁ, I. 1990: Ultrastructural changes in mouse oviduct epithelium during the estrous cycle. Scripta medica 63: 335-342

ČECH, S., LAUSCHOVÁ, I. 1996: Ultrastructural distribution pattern of glycogen in the oviduct epithelium of sex immature mouse female. In: Plzeň. Lék. Sborník 63: 175-176

ELSIMAR, M., COUTINHO, P. 1988: The pharmacological management of motility disturbance of the Fallopian tube. In: Human Reproduction. Current Status / Future Prospect. R.Lizuka, K.Semm, eds. Excerpta Medica, Amsterdam, New York, Oxford, 1988,pp. 603-608

ERICKSON-LAWRENCE, M. F., TURNER, T. T., THOMAS, T. S., OLIPHANT, G. 1989: Effect of steroid hormones on sulfated oviductal glycoprotein secretion by oviductal explants in vitro. Biol. Reprod. 40: 1311-1319

EROSHENKO, V. P. 1982: Surface changes in oviduct, uterus and vaginal cell of neonatal mice after estradiol-17 beta and insecticide chlordecone (Kepone) treatment: a scanning electron microscopic study. Biol. Reprod. 26: 707-720

FAUSSONE-PELLEGRINI, M. S., BANI, G. 1990: The muscle coat morphology of the mouse oviduct during the estrous cycle. Histol. Cytol. 2: 167-178

FISHER, D. J., DE VILLARREAL, M.1982: Effects of hormones on postimplantation mouse embryos in vitro. II. Progesterone and estrogen. J. Exp. Zool. 224: 205-210

FORCELLEDO, M. L., MORALES, P., VERA, R., QUIJADA, S., CROXATTO, H. B. 1982: Role of ovarian and adrenal progesterone in the regulation of ovum transport in pregnant rats. Biol. Reprod. 27:1033-1041

FREDRICSSON, B., HOLM, S. 1974: Dissociated response of the epithelium of the rabbit oviduct to estrogen. Biol. Reprod. 11: 40-49 
FUENTEALBA, B., NIETO, M., CROXATTO, H. B. 1988: Progesterone abbreviates the nuclear retention of estrogen receptors in the rat oviduct and counteracts estrogen action on egg transport. Biol. Reprod. 38: 63-69

GADDUM-ROSSE, P., RUMERY, R. E., BLANDAU, R. J., THIERSCH, J. B. 1975: Studies on the mucosa of postmenopausal oviducts: Surface appearance, ciliary activity and the effect of estrogen treatment. Fertil. Steril. 26: $951-969$

GUPTA, D. N., KARKUN, J. N., KAR, A. B.1969: Studies on physiology and biochemistry of the Fallopian tube: Response of the different parts of the rabbit Fallopian tube to estrogen and progesterone. Acta Biol. Med. Germ. 22: $551-559$

HOLLIS, D. E., FRITH, P. A., VAUGHAN, J. D., CHAPMAN, R. E., NANCARROW, C. D. 1984: Ultrastructural changes in the oviductal epithelium of merino ewes during the estrous cycle. Am. J. Anat. 171: 441-456

HOSHINO, K., KUMASAKA, T. 1991: Contractile responsivenes of the isolated guinea pig oviduct to autocoids at different phases of the sexual cycle or under ovarian steroids treatment. Nippon Sanka Fujinka Gakkai Zashi 43: 429-436.

KIM, N. H., FUNAHASHI, H., ABEYDEERA, L. R., MOON, S. J., PRATHER, R. S., DAY, B. N. 1996a: Effects of oviductal fluid on sperm penetration and cortical granule exocytosis during fertilization of pig oocytes in vitro. J. Reprod. Fertil. 101: 79-86

KIM, S., KORHONEN, M., WILBORN, W., FOLDESY, R., SNIPES,W., HODGEN, G. D., ANDERSON, F. D. 1996b: Antiproliferative effects of low-dose micronized progesterone. Fertil. Steril. 65: 323-331

LAPOINTE, S., CHIAN, R. C., SIRARD, M. A. 1995: Effects of estrous cycle, steroids and localization of oviductal cells on in vitro secretion of sperm motility factor(s). Theriogenology 44: 119-128

LAUSCHOVÁ, I. 1996: Ultrastructural changes in the oviduct epithelium of sexually immature mouse during postnatal development. Scripta medica 69: 251-261

MALETTE, B., FILION, B., STJACQUES, S., KAN, F. W. K., BLEAU, G.1995: Hormonal control of the biosynthesis of hamster oviductin. Microsc. Res. Technique 31: 470-477

NIEDER, G. L., MACON, G. R. 1987: Uterine and oviductal protein secretion during early pregnancy. J. Reprod. Fertil. 81: 287-294

NOVOTNÝ, R., MALÍNSKÝ, J., OBORNÁ, I., DOSTÁL, J. 1998a: Povrchový reliéf endometria v rastrovacím elektronovém mikroskopu. In: Sborník abstrakt 38. sjezdu České anatomické společnosti, Olomouc 1.-3.9.1998, Palackého univerzita, Olomouc, p. 85.

NOVOTNÝ, R., MALÍNSKÝ, J., OBORNÁ, I., DOSTÁL, J. 1998b: Ultrastruktura povrchového reliéfu endometria v elektronovém mikroskopu. In: Sborník abstrakt 38. sjezdu České anatomické společnosti, Olomouc 1.-3. 9. 1998, Palackého univerzita, Olomouc, p. 86.

NOZAKI, M., ITO, Y. 1987: Changes in physiological properties of rabbit oviduct by ovarian steroids. Am. J. Physiol. 252: 1059-1065

ODOR, D. L., GADDUM-ROSSE, P., RUMERY, R. E., BLANDAU, R. J. 1980: Cyclic variations in the oviductal ciliated cells during the menstrual cycle and after estrogen treatment in the pig-tailed monkey, Macaca nemestrina. Anat. Rec. 198: 35-57

ODOR, D. L., GADDUM-ROSSE, P., RUMERY, R. E. 1983: Secretory cells of the oviduct of the pig-tailed monkey, Macaca nemestrina. Am. J. Anat. 166: 149-172

OGUNRATI, J. O. 1992: Delta 5-3-beta-hydroxysteroid dehydrogenase activity in rat oviduct and implications of oviductal steroidogenesis. Eur. J. Obstet. Reprod. Biol. 44:145-150

PATHAK, R. K., BAJPAI, V. K., SHIPSTONE, A. C., CHANDRA, H., KARKUN, J. N. 1979: The effect of estrogen on the tubal epithelium of immature ovariectomized rhesus monkey (Macaca mulatta). Endokrinologie 73:134-144

PURI, R. K., ROY, S. K. 1981: Estradiol binding in different parts of the rabbit oviduct during egg transport. Endokrinologie 78: $12-20$

REYNOLDS, E. S. 1963: The use of lead citrate at high $\mathrm{pH}$ as an electronopaque stain in electron microscopy. J. Cell Biol. 17: 208-212

REUTER, L. M., ODAY-BOWMAN, M. B., MAVROGIANIS, P. A., FAZLEABAS, A. T., VERHAGE, H. G. 1994: In vitro incubation of golden (Syrian) hamster ovarian oocytes and human sperm with a human oviduct specific glycoprotein. Mol. Reprod. Develop. 38: 160-163.

ROBLERO, R. S., GARAVAGNO, A. C. 1979: Effect of oestradiol-17 beta and progesterone on oviductal transport and early development of mouse embryos. J. Reprod. Fertil. 57: 91-95

SATHANANTHAN, H., BONGSO, A., NG, S.-CH., HO, J., MOK, H., RATNAM, S. 1990: Ultrastructure of preimplantation human embryos co-cultured with human ampullary cells. Human Reprod. 3: 309-318

SAWYER, H. R., OLSON, P. N., GORELL, T. A. 1984: Effects of progesterone on the oviductal epithelium in estrogen-primed prepubertal beagles: light and electron microscopic observations. Am. J. Anat. 169: 75-87

TAKEUCHI, K., NAGATA, Y., SANDOW, B. A., HODGEN, G. D. 1992: Primary culture of human Fallopian tube epithelial cells and co-culture of early mouse pre-embryos. Mol. Reprod. Develop. 32: 236-242

UHRÍN, V. 1992: Funkčná morfológia epitelov vajcovodu a maternice kravy. Výskumný ústav živočíšnej výroby, Nitra, p. 169 
VERHAGE, H. G., BRENNER, R. M. 1975: Estradiol-induced differentiation of the oviductal epithelium in ovariectomized cats. Biol. Reprod. 13: 104-111

VERHAGE, H. G., MAVROGIANIS, P. A., BOICE, M. L., LI, W., FAZLEABAS, A. T. 1990: Oviductal epithelium of the baboon: hormonal control and the immuno-gold localization of oviduct-specific glycoproteins. Am. J. Anat. 187: 81-90

YAMASHITA, S., NEWBOLD, R. R., McLACHLAN, J. A., KORACH, K. S. 1989: Developmental pattern of estrogen receptor, expression in female mouse genital tract. Endocrinology 6: 2888-2896 
Plate VI

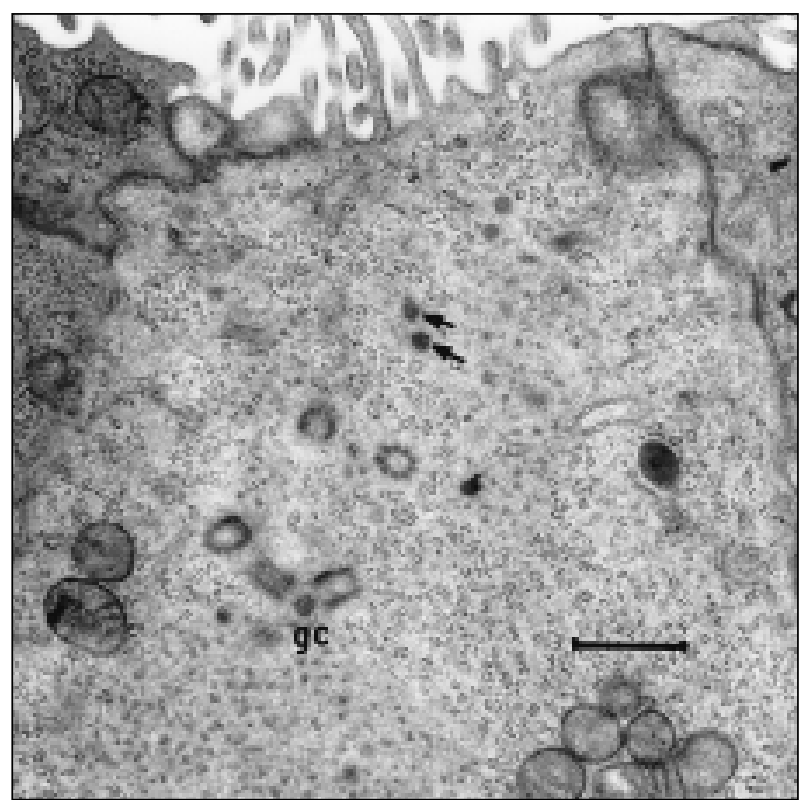

Fig. 1. Ampulla (day 14 - control): Type I cell with the signes of ciliogenesis. Generative complex (gc), deuterosomes $(\rightarrow)$. Bar $=0.5 \mu \mathrm{m}$

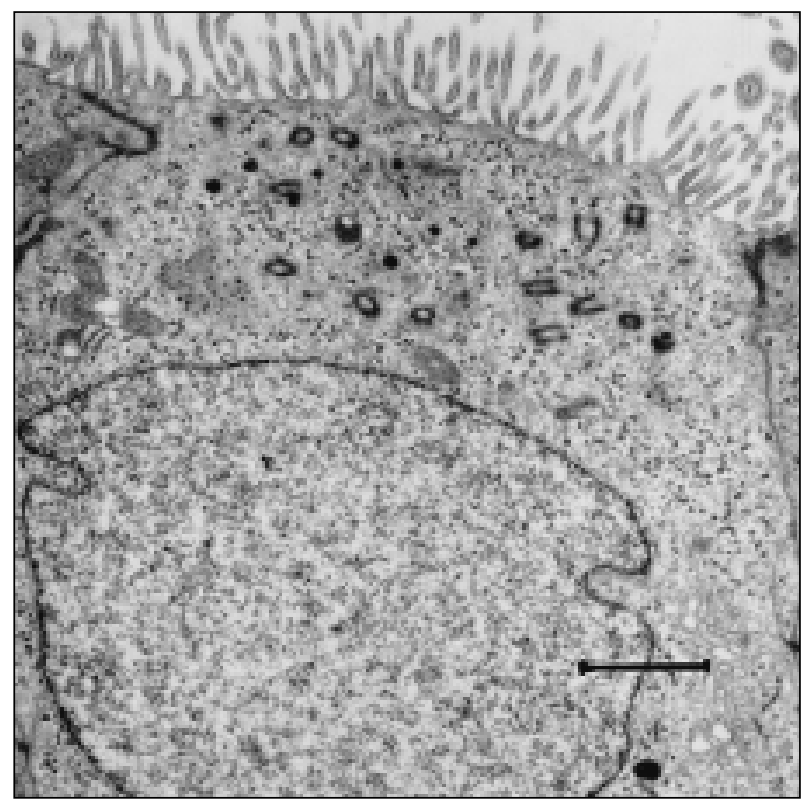

Fig. 2. Preampulla (day 14 - control): Type II cell with short microvilli on the surface and centrioles localized supranuclearly. Bar $=0.5 \mu \mathrm{m}$ 
Plate VII

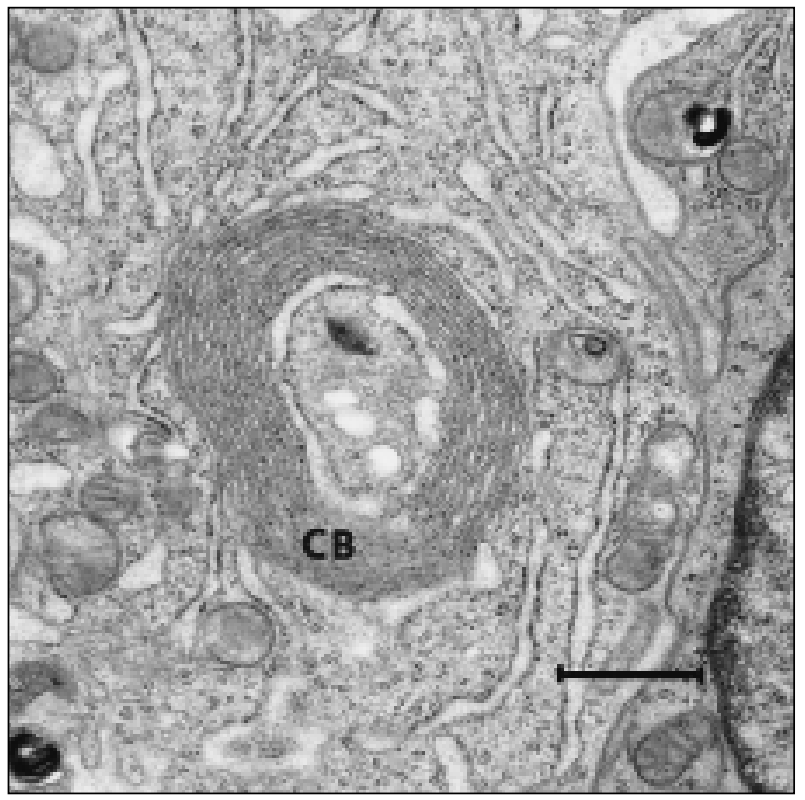

Fig. 3. Preampulla (day 14 - control): The concentric body $(\mathrm{CB})$ in secretory cell. $\mathrm{Bar}=1 \mu \mathrm{m}$

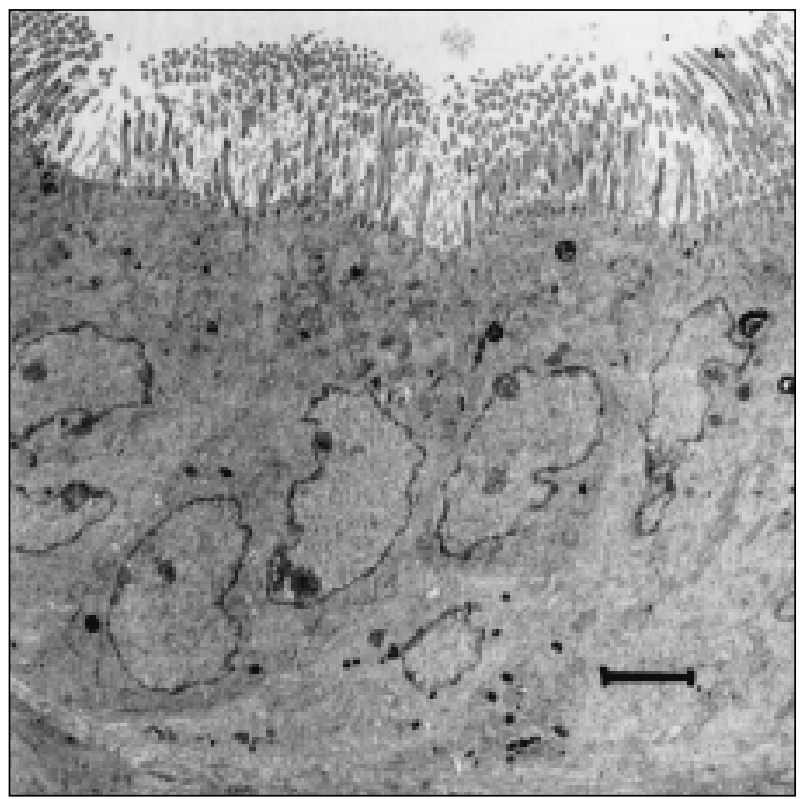

Fig. 4. Preampulla (day 28 - estrogen): Well developed ciliated cells. Bar $=2.5 \mu \mathrm{m}$ 
Plate VIII

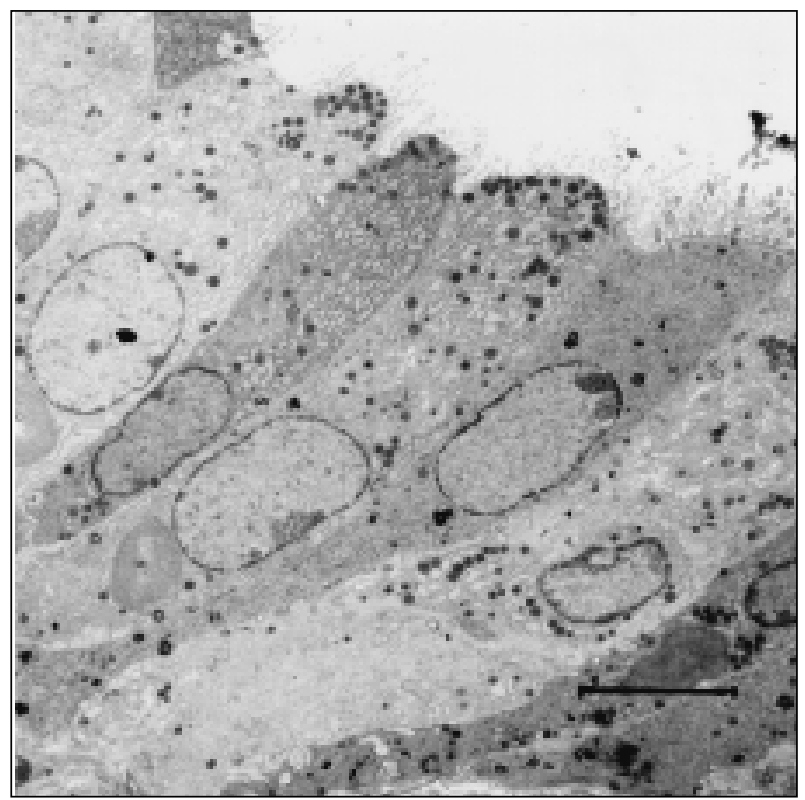

Fig. 5. Preampulla (day 28 - estrogen): Subnuclearly localized concentric bodies $(\rightarrow)$ in well developed secretory cells. $\mathrm{Bar}=5 \mu \mathrm{m}$

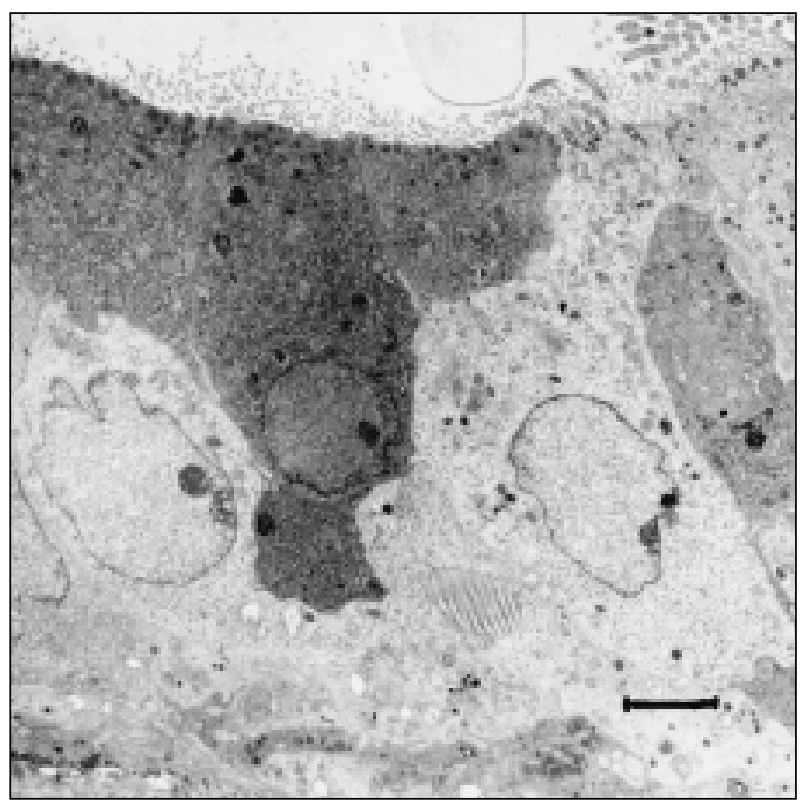

Fig. 6. Preampulla (day 14 - progesterone): Flattened surfaces of secretory cells with only a few secretory granules in the cell apices. $\mathrm{Bar}=2.5 \mu \mathrm{m}$ 
Plate IX

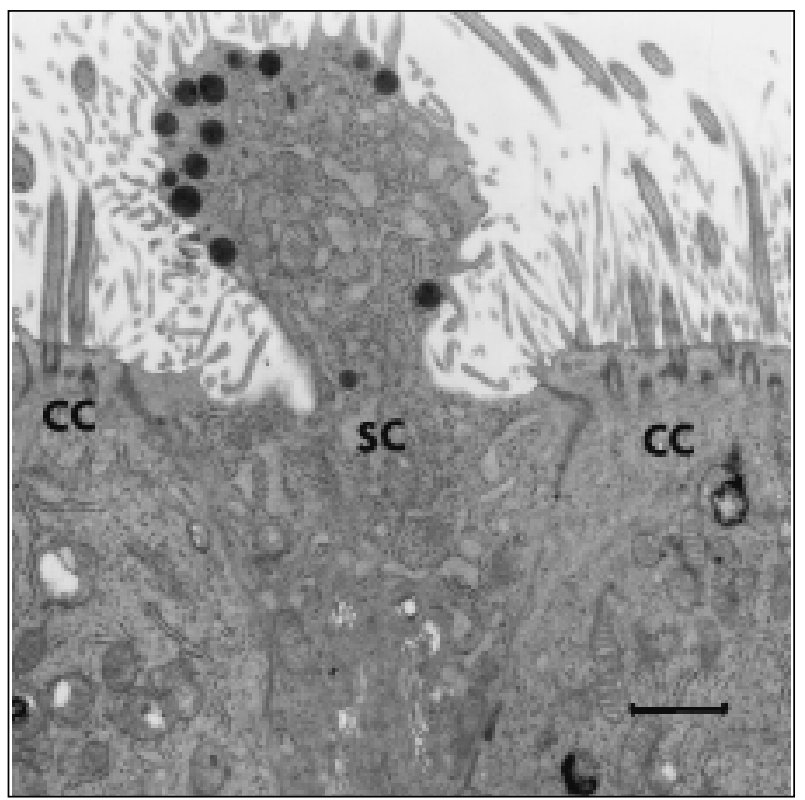

Fig. 7. Ampulla (day 28 - progesterone): Part of the cytoplasm pinched of secretory cell (SC). Poorly developed ciliary apparatus in a ciliated cell $(\mathrm{CC})$. Bar $=1 \mu \mathrm{m}$

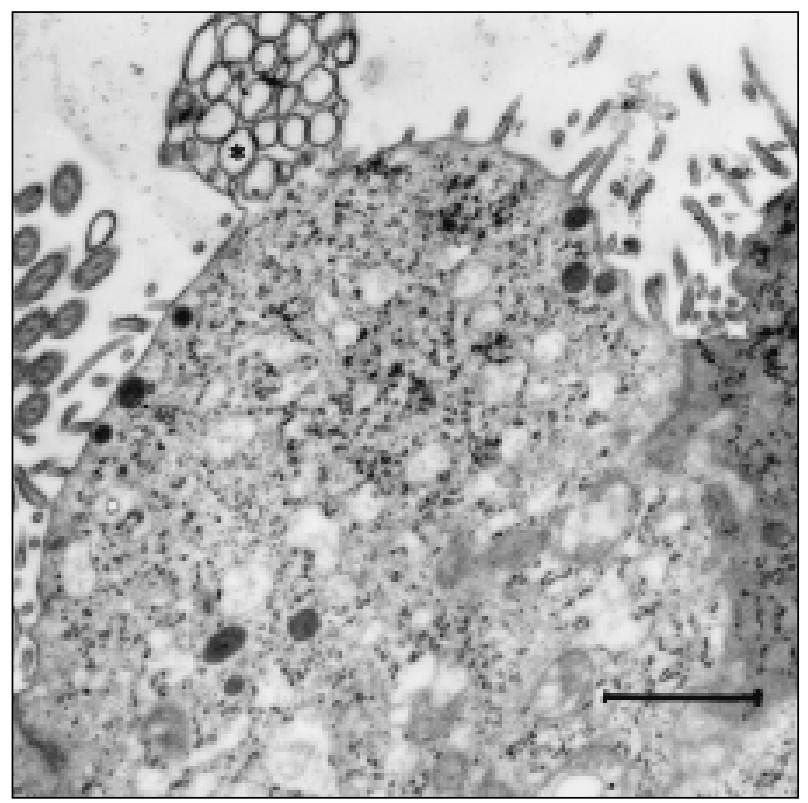

Fig. 8. Preampulla (day 28 - progesterone): The cytoplasmic process of secretory cell containing electronlucent vesicles $(*)$. Bar $=1 \mu \mathrm{m}$ 
Plate X

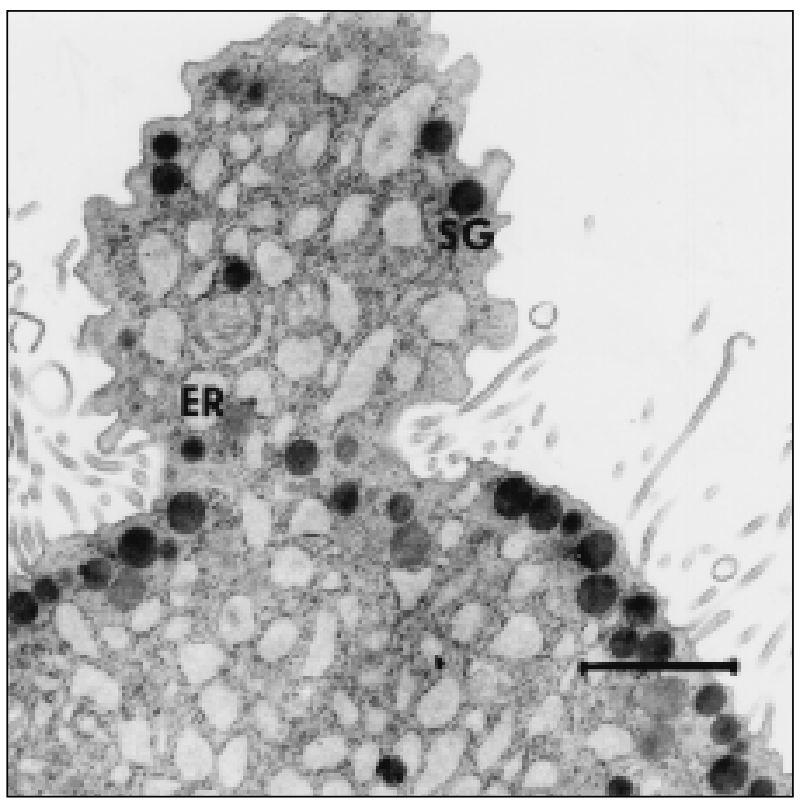

Fig. 9. Isthmus (day 21 - progesterone): The cytoplasmic process of secretory cell containing the RER (ER) and secretory granules $(\mathrm{SG})$. Bar $=1 \mu \mathrm{m}$

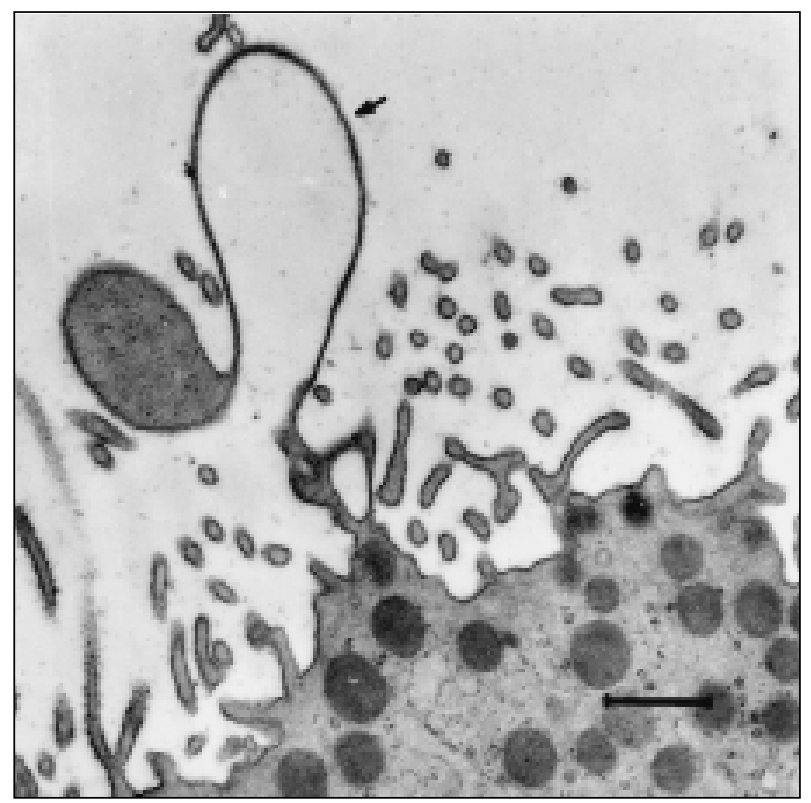

Fig.10. Isthmus (day 28 - progesterone): The apex of secretory cell - narrow stalk $(\rightarrow)$ connects the cytoplasmic segregation with cell surface. $\mathrm{Bar}=0.5 \mu \mathrm{m}$ 
Plate XI

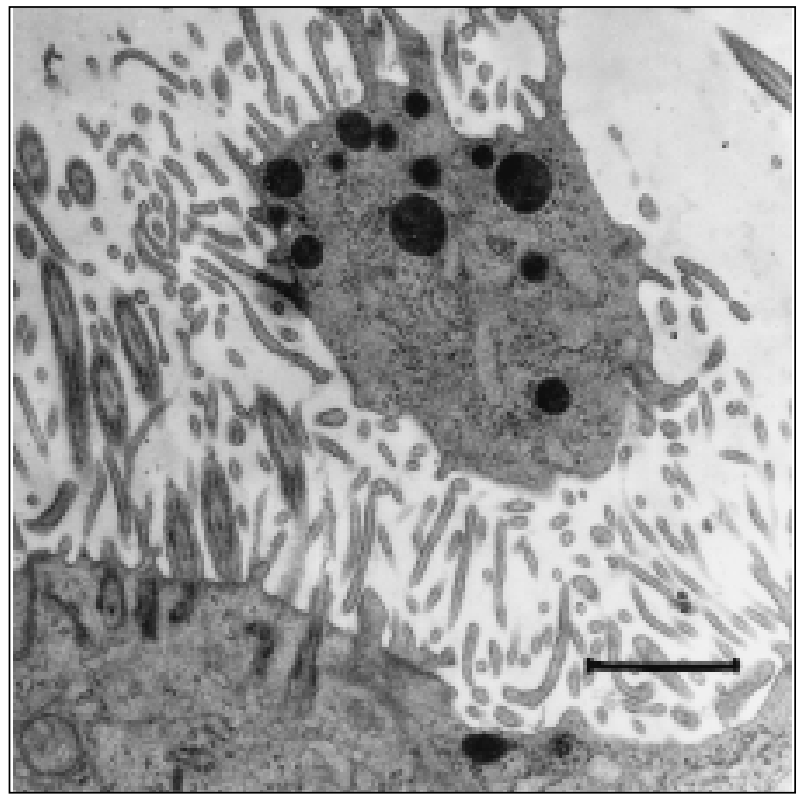

Fig. 11. Ampulla (day 28 - progesterone): Secretory cell fragment with secretory granules in the oviductal lumen. $\mathrm{Bar}=1 \mu \mathrm{m}$

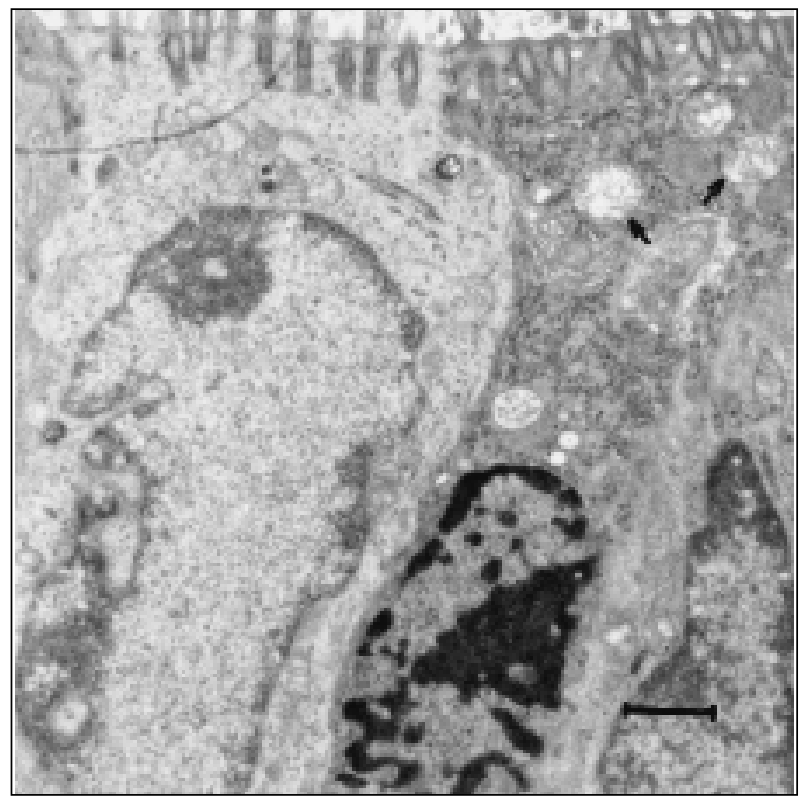

Fig. 12. Preampulla (day 28 - progesterone): Ciliated cell showing chromatin condensation and defect mitochondria $(\rightarrow)$. Bar $=1 \mu \mathrm{m}$ 